URL: http://ojs.unimal.ac.id/index.php/ekonomi_regional

\title{
Hubungan Jumlah Uang Beredar, Inflasi dan Nilai Tukar \\ Terhadap Pendapatan Nasional di Indonesia Menggunakan Model Dinamis
}

\author{
*azakiah, ${ }^{*}{ }^{\text {U Umaruddin Usman }}$ \\ * Fakultas Ekonomi dan Bisnis Universitas Malikussaleh \\ a Corresponding author:cutzakiah96@gmail.com \\ b umaruddin@unimal.ac.id
}

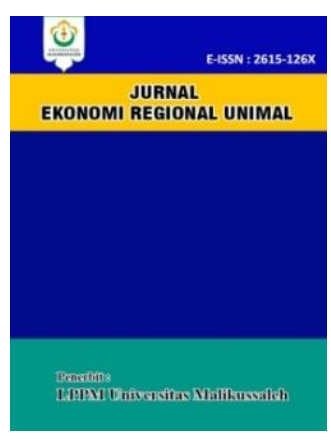

\section{A R T I C L E I NF ORMA T ION}

Keywords:

National income (GDP), money supply,inflation, exchange rate.

\section{A B S T R A C T}

This study aims to determine the effect of the money supply, inflation and the exchange rate on national income in Indonesia. This study uses time series data from 1996-2017. The tool used to analyze data is the Vector Autoregression Model (VAR) with the Impulse Respo Function (IRF). The results showed that there uses a unidirectional relationship between the variable money supply to national income and the unidirectional relationship between national income and the exchange rate. The results of the study with the analysis of the response of the money supply took one year, the inflation variable took four years, and the exchange rate variable took three years to be stable after the shock caused by other variables in the study.

\section{PENDAHULUAN}

Suatu perekonomian dapat dikatakan berkembang apabila pendapatan nasional dalam jangka panjang cenderung naik. Realisasi pendapatan nasional pada tahun 2017 lebih tinggi dari tahun 2016 mencapai 95,4 persen dari anggaran pendapatan dan belanja negara dibandingkan tahun 2016 sebesar 87,11 persen. Pemberi sumbangan terbesar dari pendapatan nasional yaitu dari industry pengolahan, sektor kontruksi, perdagangan dan pertanian.Peningkatan pendapatan nasional diikuti dengan peningkatan jumlah uang beredar pada tahun 2016 sebesar 7,70 persen . Saat jumlahuang beredar terlalu banyak, maka akan terjadi peningkatan produksi barang, oleh sebab itu produksi barang dalam negeri akan semakin tinggi. Peningkatan produksi dalam negeri yang diikuti oleh daya beli yang tinggi akan menyebabkan pendapatan nasional meningkat.

Peningkatan inflasi diikuti juga dengan peningkatan pendapatan nasional yaitu 3,61 persen pada tahun 2016 begitu juga pendaptan nasional. Sedangkan nilai tukar Rupiah yang mengalami depresiasi dan pendapatan nasional meningkat. Kurs mengalami penurunan karena sektor usaha tidak mampu membeli bahan pendukung produksi yang relatif tinggi juga.Oleh karena itu, nilai tukar (kurs) juga merupakan salah satu faktor yang dapat mempengaruhi pendapatan nasional Indonesia. Pada tabel 1 dapat dilihat perkembangan pendapatan nasionl, jumlah uang beredar, inflasi, dan Nilai tukar rupiah dalam periode pada tahun 2005-2017.

\section{Tabel 1}

\section{Data Pendapatan Nasional, Jumlah Uang} Beredar, Inflasi Dan Nilai Tukar Rupiah Tahun 2005-2017

\begin{tabular}{|c|c|c|c|c|}
\hline $\begin{array}{c}\text { Tah } \\
\text { un }\end{array}$ & $\begin{array}{c}\text { Pertumbu } \\
\text { han PDB } \\
\text { (Persen) }\end{array}$ & $\begin{array}{c}\text { Pertumbu } \\
\text { han JUB } \\
\text { (Persen) }\end{array}$ & $\begin{array}{c}\text { Pertumb } \\
\text { uhn } \\
\text { Inflasi } \\
\text { (Persen) }\end{array}$ & $\begin{array}{c}\text { Pertumbu } \\
\text { han KURS } \\
\text { (Persen) }\end{array}$ \\
\hline 2005 & 2.774 .281 & 281.905 & 17,11 & 9.830 \\
\hline 2006 & 3.339 .216 & 361.073 & 6,60 & 9.020 \\
\hline 2007 & 3.950 .893 & 460.842 & 6,59 & 9.419 \\
\hline 2008 & 4.948 .688 & 466.379 & 11,06 & 10.950 \\
\hline 2009 & 5.606 .203 & 515.824 & 2,78 & 9.400 \\
\hline 2010 & 6.864 .133 & 605.410 & 6,96 & 8.991 \\
\hline 2011 & 7.8831 .726 & 722.991 & 3,79 & 9.068 \\
\hline 2012 & 8.615 .704 & 841.625 & 4,30 & 9.670 \\
\hline 2013 & 9.546 .134 & 887.081 & 8,38 & 12.189 \\
\hline 2014 & 10.569 .705 & 942.221 & 8,36 & 12.440 \\
\hline 2015 & 11.526 .332 & 1.055 .285 & 3,35 & 13.795 \\
\hline 2016 & 12.406 .774 & 1.237 .642 & 3,32 & 13.436 \\
\hline 2017 & 13.588 .797 & 1.390 .806 & 3,61 & 13.548 \\
\hline
\end{tabular}

Sumber: Badan Pusat Statistik Indonesia, 2019 
Berdasaarkan Tabel 1 PDB di Indonesia dapat kita lihat dari tahun 2005 selalu mengalami peningkatan. Pada tahun 2005 PDB di Indonesia sebesar 5,6 persen, namun yang mengalami peningkatan hingga tahun 2017 yakni mencapai sebesar 5,19 persen. Yang terjadi permasalahan Jumlah Uang Beredar di Indonesia pada tahun 2007 meningkat mencapai sebesar 11,9 persen dari tahun sebelumnya dan PDB mengalami konstan dari tahun sebelumnya sebesar 6,3 persen. Berdasarkan data di atas menunjukkan bahwa yang terjadi di Indonesia tidak sesuai teori, karna teoriTambunan \& Nory, (2015) menyatakan bahwa apabila Jumlah Uang Beredar meningkat maka PDB juga meningkat. Tetapi yang terjadi di Indonesia sekarang apabila meningkatnya Jumlah Uang Beredar maka PDB masih tahap konstan atau tidak mengalami perkembangan yang berarti.

Berdasarkan Tabel 1 Perkembangan Inflasi di Indonesia menunjukkan hasil fluktuatif karena mengalami peningkatan dan penurunan yang tidak menentu dari waktu kewaktu. Inflasi di Indonesia dapat kita lihat Pada tahun 2005 Inflasi di Indonesia meningkat mencapai sebesar 17,11 persen, kemudian yang mengalami penurunan sampai tahun 2017 yakni mencapai sebesar3,61 persen.Yang terjadi permasalahan Inflasi di Indonesia pada tahun 2012 meningkat mencapai sebesar4,30 persen dari tahun sebelumnya dan PDB ikut mengalami peningkatan dari tahun sebelumnya yakni sebesar Rp.8.615.704 Milyar.Berdasarkan data menunjukkan bahwa yang terjadi di Indonesia tidak sesuai teori, karna teori Karlina, (2017) menyatakan apabila meningkatnya inflasi mengalami menurunkan PDB, tetapi yang terjadi di Indonesia juga sebaliknya yaitu Apabila Inflasi meningkat maka PDB akan mengalami peningkatan juga dari tahun sebelumnya.

Berdasarkan Tabel 1 perkembangan Nilai Tukar Rupiah di Indonesia dapat kita lihat dari 2005 selalu mengalami peningkatan.Pada tahun 2005 Nilai Tukar Rupiah di Indonesia meningkat mencapai sebesar 8,6 persen, kemudian tahun 2017 nilai tukar Rupiah menguat sebesar 0,27 persen.Yang tarjadi permasalahan Nilai Tukar Rupiah di Indonesia pada tahun 2013 mengalami depresiasi sebesar 26,42 persen dari tahun sebelumnya dan PDB juga ikut mengalami peningkatan dari tahun sebelumnya yakni sebesar 5,78 persen. Berdasarkan data menunjukkan bahwa yang terjadi diindonesia tidak sesuai teori, karena teorinya menurut Luwihadi et al., (2017) menyatakan bahwa apabila melemahnya Nilai
Tukar Rupiah maka PDB menurun, tetapi yang terjadi di Indonesia sekarang juga sebaliknya yaitu Nilai Tukar Rupiah meningkat maka PDB juga meningkat dari tahun sebelumnya.

Oleh karena itu peneliti ingin mengkaji pengaruh jumlah uang beredar, inflasi dan nilai tukar rupiah terhadap dari pendapatan nasional di Indonesia.Karena keterbatasan data yang ada pada waktu peneliti hanya dapat dibahas empat faktor ini yang meyakini menjadi objek dan subtansidalam peningkatan pendapatan nasional di Indonesia.

Tujuan penelitian adalah untuk menganalisis hubungan jumlah uang beredar, inflasi dan nilai tukar rupiah terhadap pendapatan nasional di Indonesia menggunakan model dinamis. Selanjutnya bagian kedua penelitian ini membahas tinjauan teoritis dari variabel-variabel terkait, teknik analisis dipaparkan dibagian tiga, untuk melihat hasil dari pembahasannya dipaparkan di bagian ke empat, dan bagian akhir merupakan kesimpulan dan saran.

\section{TINJAUAN TEORITIS}

\section{Pendapatan Nasional}

Sukirno, (2011)mengatakan bahwa Pendapatan Domestik Bruto (PDB)sebagai nilai barang dan jasa dalam suatu negarayang diproduksikan oleh faktorfaktor produksimilik warga negara tersebut dan negaraasing.

\section{Jumlah Uang Beredar}

Putong \& Andjaswati, (2008) menunjukkan bahwa jumlah uang beredar merupakan total persediaan uang dalam suatu perekonomian pada suatu saat tertentu (biasanya satu tahun anggaran).

Menurut Fidaus \& Maya, (2011) teori jumlah uang beredar yaitu Stok jumlah uang beredar dalam perekonomian negara akan menentukan laju harga barang. Ada keterkaitan antara perubahan dalam jumlah uang beredar dengan perubahan pendapatan nasisonal. Fluktuasi ekonomi lebih disebabkan oleh perubahan jumlah uang beredar merupakan faktor penting yang menyebabkan perubahan penerimaan pendapatan nasional.Dapat disimpulkan bahwa apabila jumlah uang beredar meningkat maka pendapatan nasional meningkat berkorelsi positif.

Jika dibandingkan penelitian penulis dengan penelitian sebelumnya yaitu menurut penelitian dari Tambunan \& Nory, (2015) Pengaruh Jumlah Uang Beredar Dan Pengeluaran Pemerintah Terhadap Produk Domestik Bruto (PDB) Indonesia. Berdasarkan hasil penelitian diperoleh bahwa Jumlah Uang Beredar dan Pengeluaran Pemerintah berpengaruh terhadap Produk Domestik Bruto 
Indonesia.Secara parsial variabel JumlahUang Beredar dampen geluaranpemerintah memiliki pengaruhpositif dan signifikan terhadapProduk Domestik Bruto Indonesia. Metode yang digunakan berbeda dengan penelitian penulis yang menggunakan VectorAutoregression Model.

\section{Inflasi}

Inflasi merupakan Peningkata harga secara terus-menerus dan kenaikan harga yang terjadi pada seluruh kelompok barang dan jasa(Pohan, 2008). Menurut Samuelsoon \& Nordhaus, (2004) mengatakan bahwa kenyataan empiris menunjukkan bahwa pada beberapa negara, inflasi berkorelasi dengan tingkat pendapatan nasional.Kenyataan tersebut mengindikasikan bahwa dengan tingkat Inflasi yang tinggi dapatdiharapkan tingkat pendapatan negara meningkat pula.Indikasi tersebut kemungkinan disebabkanoleh korelasi positif antara inflasi dan aktifitas ekonomi riil di banyak negara berkembang serta kemungkinan adanya keterkaitan erat antara kebijakan moneterdengan kebijakan sektor riil di negara-negara tersebut.

Jika dibandingkan penelitian penulis dengan penelitian sebelumnya yaitu menurut penelitian dari Karlina, (2017) dengan judul Pengaruh Tingkat Inflasi, Indeks Harga Konsumen Terhadap PDB di Indonesia 2011-2015. Metode quantitative dengan multiple regression. Dalam penelitian ini, ditemukan bahwa perubahan Produk Domestik Bruto (PDB) di Indonesia dari tahun 2011 - 2015 dipengaruhi oleh indeks harga dan tingkat inflasi dan tidak pada IHK.

\section{Nilai Tukar}

Menurut Munthe \& Hamdi, (2015) Nilai tukar merupakan harga mata uang local terhadap mata uang asing. Jadi, nilai tukar adalah nilai dari suatu mata uang rupiah yang ditranslasikan ke dalam mata uang negara dan lain. Kurs perbandingan hargaLuwihadi et al., (2017) merupakan kurs mencapai pertumbuhan ekonomi disuatu Negara,harga stabilitas, nilai kebijakan tingkat atau bunga bank, dan pembayan neraca keseimbangan, untuk serta kesepakatan mencapai kerja.

Menurut Kristiawati, (2013) menyebutkan bahwa pergerakan nilai tukar berpengaruh secara positif terhadap pendapatan nasional yang berarti apabila nilai tukar mengalami kenaikan, maka pendapatan nasional seharusnya juga mengalami kenaikan, kecuali jika kondisi hutang negara tinggi. Namun, pendapatan nasional dari hasil ekonomi masyarakat akan mengalami penurunan karena peningkatan nilai tukar Rupiah akan mendorong kenaikan harga barang hingga menjadikan ekonomi kurang produktif.

Jika dibandingkan penelitian penulis dengan penelitian sebelumnya yaitu menurut penelitian dari Verayanti, (2007) dengan judul "Pengaruh Inflasi, Ekspor Dan KursTerhadap Produk Domestik Bruto Indonesia Tahun 2000-2004".Berdasarkan hasil regresi data panel menggunakan uji statistik yaitu uji $\mathrm{F}$, uji t dan menunjukkan bahwa inflasi, ekspor, dan kurs berpengaruh signifikan terhadap produkdomestik bruto. Variabel inflasi dan kurs berpengaruh negatif sedangkan ekspor berpengaruh positif, sedangkan untuk pengujian Fhitung, disimpulkan bahwa secara serentak inflasi, ekspor dan kurs berpengaruh terhadapproduk domestik bruto.

\section{Kerangka Konseptual}

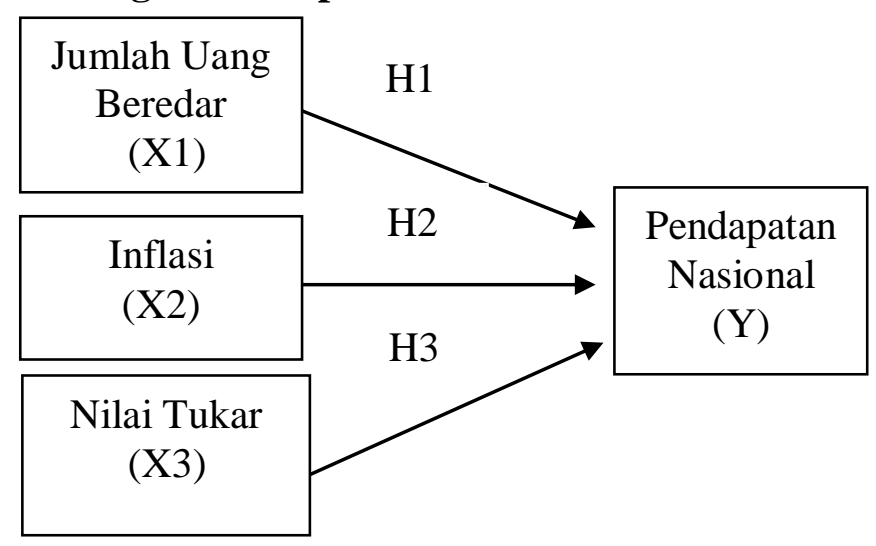

\section{Gambar 1 Kerangka Konseptual}

Berdasarkan kerangka konseptual dalam penelitian ini menggunakan variabel independent jumlah uang beredar sebagai X1, inflasi sebagai X2 dan nilai tukar rupiah sebagai X3 berpengaruh terhadap pendapatan nasional sebagai variabel dependent (Y). secara parsial masing-masing akan di uji dengan menggunakan uji t, sedangkan secara similtan akan digunakan uji f.

\section{Hipotesis}

H1 : Didugajumlah uang beredar berpengaruh terhadap pendapatan nasional di Indonesia tahun 1996-2017

H2 : Didugainflasi berpengaruh terhadap pendapatan nasional di Indonesia tahun 1996-2017

H3 : Diduganilai tukar Rupiah berpengaruh terhadap pendapatan nasional di Indonesia tahun 1996-2017 


\section{METODOLOGI PENELITIAN}

\section{Data dan Sumber Data}

Sumber data dalam penelitian adalah subjek dari mana data tesebut dapat diperoleh Arikunto, (2010).Penelitian ini menggunakan data sekunder yang merupakan data runtutan waktu (time series) dari periode 1996-2017. Adapun data yang digunakan dan diperoleh berasal dari Badan Pusat Statistik (BPS), dan SEKI(Statistik Ekonomi Keuangan Indonesia).

\section{Operasional variabel}

Operasionalisasi variabel adalah sebagai petunjuk bagaimana variabel-variabel dalam penelitian diukur. Untuk mengatahui dan mempermudah pemahaman terhadap variabelvariabel yang akan dianalisis dalam penelitian ini, maka perlu dirumuskan operasionaliasasi variabel yaitu sebagai berikut:

1. Pendapatan nasional (Y) adalah jumlah pendapatan dari hasil barang dan jasa dalam suatu wilayah tertentu yang dinyatakan dalam satuan milyaran.

2. Jumlah Uang Beredar (X1) adalah uang yang berada ditangan masyarakat yang dinyatakan dalam satuan milyaran.

3. Inflasi (X2) adalah tingkat kenaikan harga barang yang dinyatakan dalam satuan Persen $(\%)$.

4. Nilai Tukar Rupiah (X3) adalah harga mata uang local terhadap harga mata uang asing yang dinyatakan dalam satuan US Dollar (USD).

\section{Metode Analisa Data}

Model dasar persamaan estimasi OLS (Ordinary Least Square) akan dikembangkan menjadi model dinamis dan menaksirkan variabel dependen berdasarkan regresi, dengan rumus :

$$
\mathrm{Y}=\mathrm{a}+\beta X_{1}+\beta X_{2}+\beta \mathrm{X}_{3}+\mathrm{e}
$$

Persamaan Log, dengan rumus:

$$
\log Y_{t}=a+\log \beta X_{1}+\beta X_{2}+\log \beta X_{3}+e_{t}
$$

Dimana :

$\mathrm{Y}=$ Pendapatan Nasional

$\mathrm{X} 1=$ Jumlah Uang Beredar

$\mathrm{X} 2$ = Inflasi

$\mathrm{X} 3$ = Nilai Tukar Rupiah

$\mathrm{A}=$ JumlahObservasi

$\mathrm{B}=$ Koefisien Regres

$\mathrm{e} \quad=$ Error Tearm (variabelpengganggu)

Log $=$ Untuk mengseragamkan data

Penelitian menggunakan model VAR. Model Vactor Autogeression model (VAR) merupakan salah satu metode time series yang digunakan dalam penelitian, terutama dalam bidang ekonomi. Dengan demikian VAR adalah model non struktur model tidak teoritis (ateoritis). Model VAR adalah model linier sehingga kita tidak perlu khawatir tentang bentuk model serta model VAR mudah diestimasi dengan menggunakan metode OLS (Widarjono, 2018).

Tahapan Uji Model VAR (Widarjono, 2017) adalah sebagai berikut:

\section{Uji Stasioner}

Uji stasioneritas/ uji akar-akar unit (Unit Root Test) dilakukan untuk menentukan stasioner tidaknya sebuah variabel. Data dikatakan stasioner apabila data tersebut mendekati rata-ratanya, dan apabila data yang diamati dalam uji derajat integrasi (Integration Test) sampai memperoleh data yang stasioner. Bentuk persaman uji stasioneritas dengan analisis ADF (Augemented Dickey Fuller)

Apabila dalam pengujian ini menunjukkan nilai ADFstatistik lebih besar dari pada Mackinnon Critical Value maka data tersebut stasioner, dan sebaiknya apabila nila ADF statistik lebih kecil dari pada Mackinnon Critical Value maka data tersebut tidak stasioner.

\section{Penentuan Lag Optimal}

Tahap kedua di dalam analisis VAR adalah penentuan lag optimum. Penentuan jumlah lag dalam model VAR ditentukan pada kriteria informasi yang direkomendasikan oleh nilai terkecil dari Final Prediction Error (FPE), Akaike Information Criterion (AIC), Schwarz Criterion (SC), dan Hannan-Quinn (HQ). Program Eviews telah memberi petunjuk tanda bintang bagi lag yang ditetapkan sebagai lag optimum.

\section{Uji Kausalitas Granger}

Metode yang digunakan untuk menganalisis hubungan kausalitas antar variabel yang diamati adalah dengan uji kausalitas Granger.

\section{Uji Kointegrasi}

Data time series seringkali menunjukkan kondisi yang tidak stasioner pada tingkat level (Widarjano, 2013). Namun seringkali menunjukkan stasioner melalui tingkat difference. Oleh karena itu perlu dilakukan uji kointegrasi untuk mengetahui apakah variabel bebas dan terikat terkointegrasi sehingga ada hubungan jangka panjang antar variabel. Dalam penelitian ini untuk melihat kointegrasi maka dilakukan melalui Johansen 
cointegrasi test. Apabila nilai trace statistic < critical value,begitu juga nilai max eign stat < critical value,ini berarti bahwa tidak terdapat kointegrasi di dalam model persamaan tersebut dan begitu pula sebaliknya.

\section{Uji Impulse Response}

IRF menunjukkan bagaimana respon dari setiap variabel endogen sepanjang waktu terhadap kejutan dari variabel itu sendiri dan variabel endogen lainnya.

\section{Uji Forecast Error Variance decomposition (FEVD)}

Uji FEVD ini dilakukan untuk melihat seberapa besar pengaruh acakk guncangan (random shock) dari variabel tertentu terhadap variabel endogen.

\section{HASIL PENELITIAN DAN PEMBAHASAN}

\section{Perkembangan Pendapatan Nasional}

Pendapatan nasional atau produk domestik bruto ini sebagai sejumlah nilai barang dan jasa yang diproduksikan oleh suatu Negara dalam periode tertentu atau satu tahun. Berdasarkan data yang diperoleh maka pergerakan tingkat pendapatan nasional dari 1996-2017 bisa dilihat pada Gambar 2.

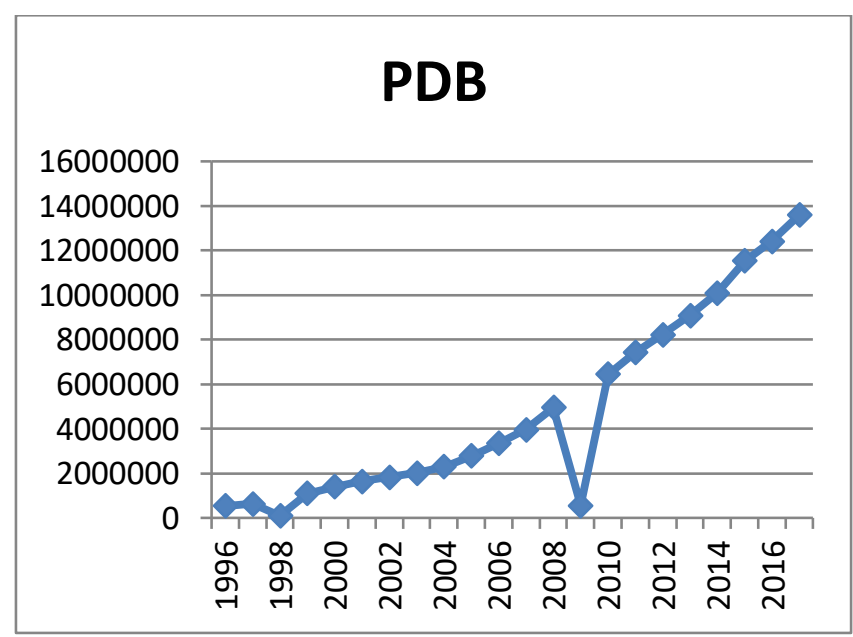

Sumber: Badan Pusat Statistik, (2019)

\section{Gambar 2}

\section{Perkembangan Pendapatan Nasional}

Berdasarkan Gambar 2 perkembangan pendapatan nasionalmenunjukkan hasil fluktuatif karna mengalami kanaikan dan penurunan yang tidak menentu dari waktu kewaktu.kenaikan berada pada tahun 2008 dan pendapatan nasional terendah berada pada tahun 2009. Meningkatnya jumlah barang konsumsi menyebabkan perekonomian bertumbuh, dan meningkatnya skala omset penjualan perusahaan, karena masyarakat yang bersifat konsumtif.Dengan meningkatnya omset penjualan maka keuntungan perusahaan juga meningkat.

\section{Perkembangan Jumlah Uang beredar}

Menurut Setiawina, (2004) jumlah uang beredar merupakan nominal dari seberapa banyak uang beredar yang ada ditangan masyarakat. Jumlah uang beredar semakin bertambah banyak jumlahnya setiap tahun. Hal ini menunjukkan bahwa permintaan masyarakat akan uang semakin bertambah setiap tahunnya dan ini dapat disebabkan berbagai hal termasuk tingkat konsumsi masyarakat yang semakin bertambah setiap saat. Berdasarkan data yang diperoleh maka pergerakan tingkat inflasi dari 1996-2017 bisa dilihat pada gambar3.

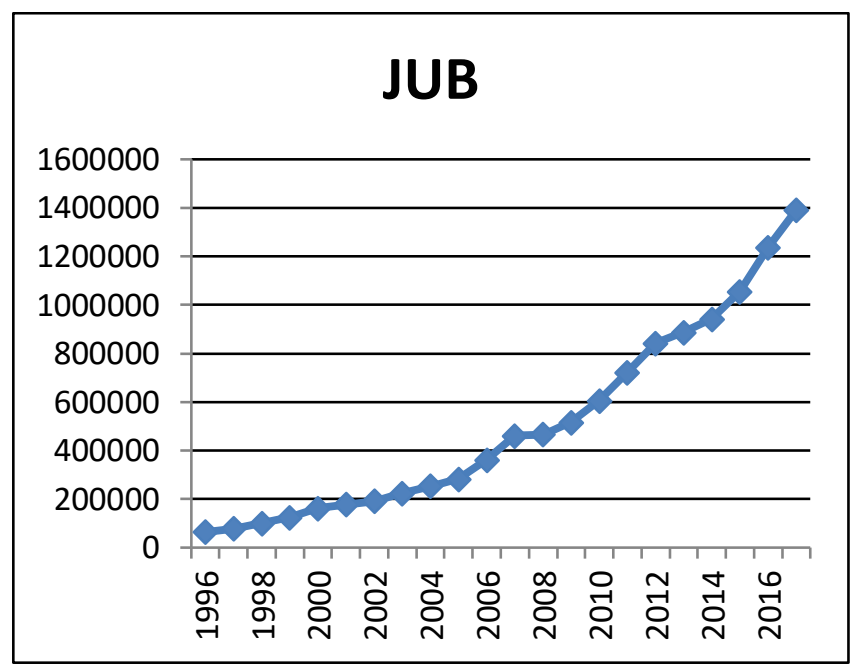

Sumber: Badan Pusat Statistik, (2019)

\section{Gambar 3}

\section{Perkembangan Jumlah Uang beredar}

Berdasarkan Gambar 3 dapat dilihat bahwa perkembangan jumlah uang beredar dari tahun 1996 mengalami peningkatan dari tahun ke tahun sampai dengan tahun 2017. Dengan bertambahnnya jumlah uang beredar di masyarakat cenderung akan menambah konsumsinya melalui belanja. maka akan menyebabkan naiknya harga dikarenakan bertambahnya permintaan dari masyarakat, meskipun pertumbuhannya mengalami naik turun.

\section{Perkembangan Inflasi}

Inflasi merupakan meningkatnya harga suatu barang secara terus menerus serta dapat menurunkan pertumbuhan ekonomi suatu negara. Salah satu penyebab inflasi karena adanya kenaikan permintaan yang akan mengakibatkan harga naik karena penawaran tetap sehingga harga barang di Indonesia menjadi lebih mahal. Laju inflasi 
merupakan suatu fenomena ekonomi yang sering terjadi pada perekonomian suatu negara. Inflasi akan menjadi suatu masalah ekonomi yang serius ketika inflasi terjadi dalam jangka waktu yang lama dan inflasinya tinggi. Berdasarkan data yang diperoleh maka pergerakan tingkat inflasi dari 1996-2017 bisa dilihat pada gambar 4 .

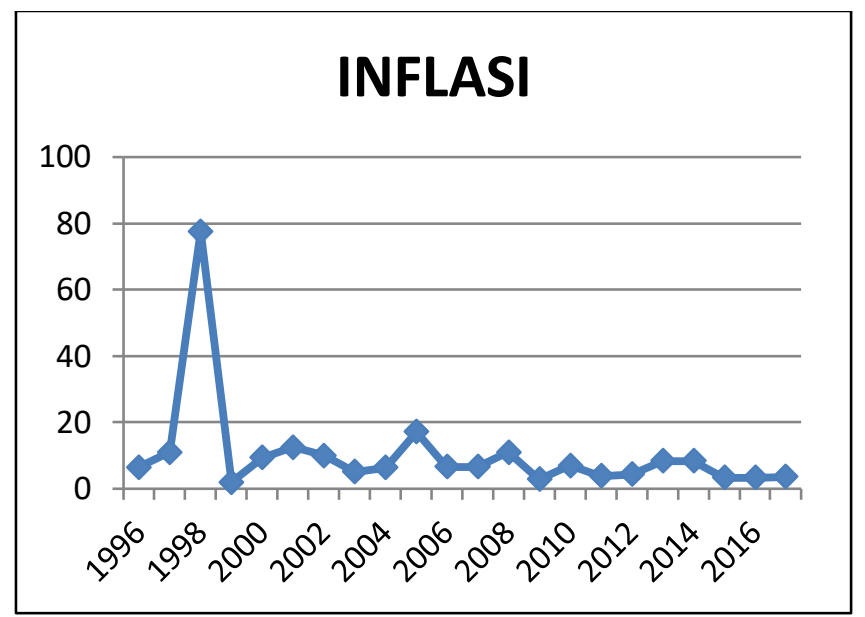

Sumber: Badan Pusat Statistik, (2019)

Gambar 4

Perkembangan Inflasi

Berdasarkan Gambar 4 dapat kita lihat bahwa perkembangan tingkat inflasi di Indonesia sangat bervariasi dan berfluktuasi mulai dari yang tertinggi yaitu pada tahun 1996, sedangkan yang terendah berada di tahun 1999. Tingginya tingkat inflasi di Indonesia akan membuat penggunaan konsumsi masyarakat akan kebutuhan barang dan jasa dalam negeri menurun. Penyebab tingginya inflasi di Indonesia dikarenakan adanya kenaikan permintaan yang mengakibatkan harga naik karena penawaran tetap sehingga harga barang di Indonesia menjadi lebih mahal. Jika tingkat inflasi terus melambung tinggi ini akan menghambat proses pembangunan dan pertumbuhan ekonomi Indonesia.

\section{Perkembangan Nilai Tukar Rupiah}

Kurs sebagai indikator yang mempengaruhi aktivitas dipasar saham atau pasar uang karena investor cenderung akan berhati-hati untuk melakukan investasi. Dengan adanya lonjakanlonjakan dratis pada tingkat kurs tersebut ini akan membuat para produsen kesulitan mendapatkan bahan baku,barang modal dan barang modal. Berdasarkan data yang diperoleh maka pergerakan tingkat inflasi dari 1996-2017 bisa dilihat pada gambar 5 .

\section{KURS}

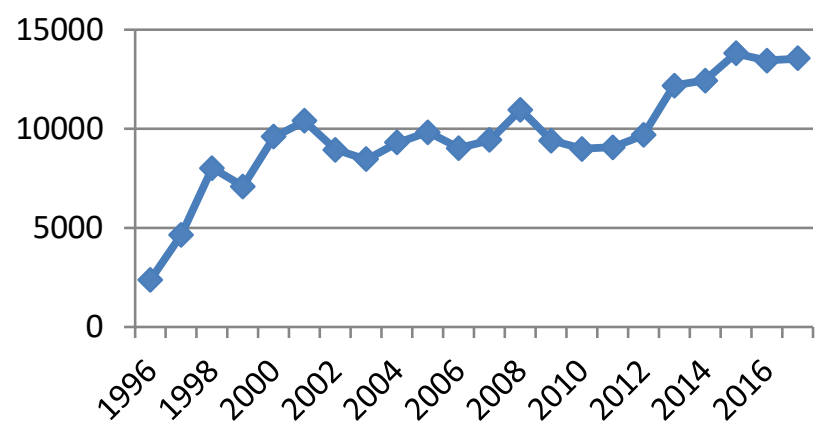

Sumber: Badan Pusat Statistik, (2019)

Gambar 5

Perkembangan Nilai Tukar Rupiah

Berdasarkan gambar 5 dapat kita lihat perkembangan nilai tukar rupiah mulai kenaikan tertinggi berada ditahun 2013 dan juga mengalami naik turun sampai tahun 2017 yang tidak menentu dari tahun ke tahun. Indonesia sebagai Negara yang banyak mengimpor bahan baku industri mengalami dampak dan ketidakstabilan kurs sehingga menyebabkan harga barang-barang milik Indonesia mengalami peningkatan. Dengan melemahnya rupiah menyebabkan perekonomian Indonesia menjadi goyah dan dilanda krisis okonomi dan kepercayaaan terhadap mata uang dalam negeri.

\section{Hasil Penelitian \\ Uji OLS Regresi Linier Berganda}

Analisis regresi linier sederhana adalah hubungan secara linier antara satu variabel independen (X) dengan variabel dependen (Y). Analisis ini untuk mengetahui arah hubungan antara variabel independen dengan variabel dependen apakah positif atau negatif dan untuk memprediksi nilai dari penurunan dapat dilihat sebagai berikut:

\section{Tabel 2}

\section{Estimasi OLS (Regresi Linier Berganda)}

\begin{tabular}{lrrrr}
\multicolumn{1}{c}{ Variable } & Coefficient Std. Error & t-Statistic & Prob. \\
\hline \hline \multicolumn{1}{c}{ C } & 0.867192 & 2.979716 & 0.291032 & 0.7744 \\
LOG(JUB) & 0.911573 & 0.236213 & 3.859110 & 0.0011 \\
INFLASI & -0.029132 & 0.008862 & -3.287114 & 0.0041 \\
LOG(KURS) & 0.286759 & 0.531819 & 0.539203 & 0.5964 \\
\hline \hline R-squared & 0.843293 & Mean dependent var & 14.82902 \\
Adjusted R- & & & \\
squared & 0.817175 & S.D. dependent var & 1.272107 \\
$\begin{array}{l}\text { F-statistic } \\
\text { Prob(F- }\end{array}$ & 32.28794 & Durbin-Watson stat & 2.364445 \\
statistic) & 0.000000 & & & \\
\hline \hline
\end{tabular}

Sumber: Hasil Pengolahan Data, 2019 
LOGPDB $=0.867192+0.911573$ LOGJUB 0.029132 INFLASI + 0.286759 LOGKURS

Adapun interpretasi persamaannya adalah sebagai berikut:

\section{Lag Optimal}

Tabel 4

Panjang Lag Length Berdasarkan Beberapa Kriteria

1. Constanta $=0.867192$

Apabila jub, inflasi dan kurs bernilai konstan maka pendapatan nasional juga 0
akan konstan sebesar 0.867192 persen.

2. Koefisien jub $=0.911573$

Apabila jub meningkat sebesar 1 persen maka pendapatan nasional akan meningkat sebesar 0.911573 persen.

3. Koefisien inflasi $=-0.029132$

Apabila inflasi meningkat sebesar 1 persen maka pendapatan nasional akan menurun sebesar -0.029132 persen.

4. Koefesien kurs $=0.286759$

Apabila kurs meningkat sebesar 1 persen maka pendapatan nasional meningkat 0.286759 persen.

\section{Hasil Estimasi Dengan Menggunakan Model VAR}

\section{Uji Stasioner}

Berikut ini pengujian stasioner dengan menggunakan ADF pada tabel 3 berikut ini:

Tabel 3

Uji Akar Menggunakan Augmented DickeyFuller (ADF)

\begin{tabular}{|l|c|}
\hline \multicolumn{1}{|c|}{ Variabel } & $\begin{array}{c}\text { 1th } \\
\text { Difference }\end{array}$ \\
\hline Pendapatan nasional & 0,0000 \\
\hline Jub & 0,0166 \\
\hline Inflasi & 0,0000 \\
\hline Kurs & 0.0104 \\
\hline
\end{tabular}

Sumber: Hasil Pengolahan Data, 2019

Berdasarkan tabel 3 dapat dijelaskan bahwa hasil uji unit root pada tingkat signifikansi 5 persen, variabel PDB, JUB, INFLASI dan KURS stasioner pada first difference. Karena variabel PDB, JUB, INFLASI dan KURS memiliki probabilitas lebih kecil dari tingkat pengujian alpha 5 persen. Dengan demikian variabel PDB, JUB, INFLASI dan KURS stasioner pada tingkat first difference.
Sumber: Hasil Pengolahan Data, 2019

Berdasarkan Tabel 4 Kriteria LR, FPE, AIC, SC, dan HQ memilih lag order 1. Dengan demikian dalam penelitian ini panjang lag optimal yang akan dipakai adalah 1. Implikasinya dari sisi ekonomi, penggunaan 1 lag sebagai lag optimal artinya semua variabel penelitian yang dipergunakan dalam persamaan saling mempengaruhi satu sama lain bukan saja pada periode yang sama namun variabel-variabel tersebut saling terkait hanya satu periode.

\section{Pengujian Stabilitas VAR}

\section{Tabel 5}

VAR Stability Condition Check

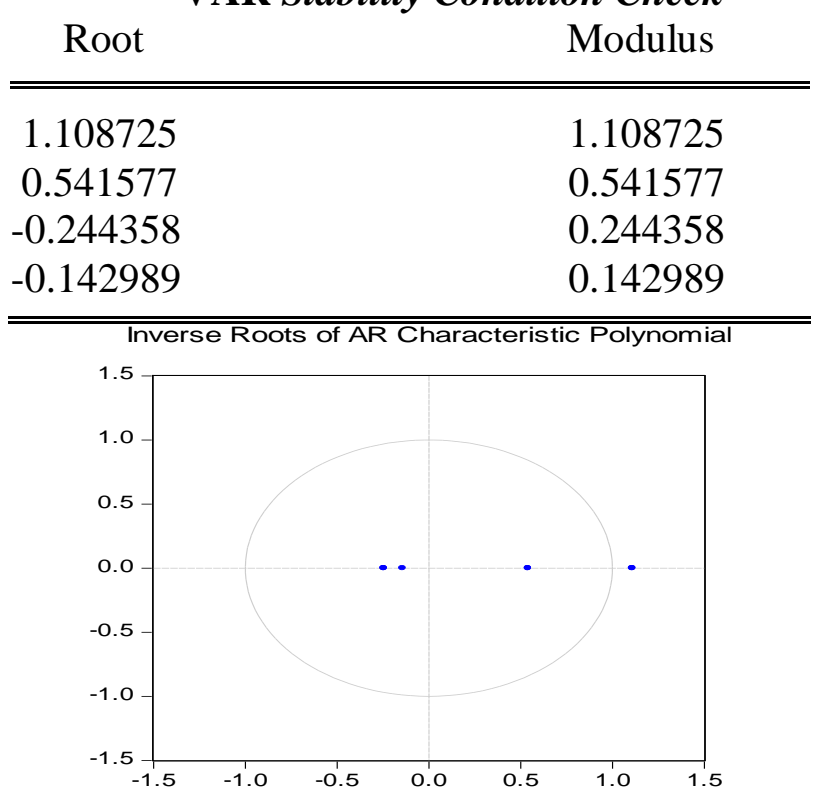

Sumber: Hasil Pengolahan Data, 2019

Keterangan: No root lies outside the unit circle.

VAR satisfies the stabilitycondition.

Berdasarkan Hasil pengujian stabilitas VAR pada tabel 5 menunjukkan bahwa persamaan VAR memiliki nilai modulus 1.108725 dan yang lainnya kurang dari satu pada lag 1, sehingga dapat disimpulkan bahwa model VAR yang dibentuk sudah stabil pada lag optimal yaitu lag 1 . 
Uji Kausalitas Granger

Tabel 6

Granger Causality Test Lag 1 mempengaruhi nilai tukar rupiah (KURS) dengan nilai prob lebih kecil dari 0,05 yaitu 0.0107 berarti tolak hipotesis nol dan variabel nilai tukar rupiah (KURS) secara statistik tidak signifikan ${ }^{P r o b}$ mempengaruhi variabel pendapatan nasional (PDB) yang dibuktikan dengan nilai prob variabel lebih

Null Hypothesis:

Obs F-Statistic

opesar dari 0,05 yaitu 0,6155 berarti terima hipotesis

DJUB does not Granger Cause DPDB

$20 \quad 25.6243$

DPDB does not Granger Cause DJUB

0.00022

DINFLASI does not Granger Cause

DPDB

DPDB does not Granger Cause

DINFLASI
$20 \quad 0.04006$

2.22478

\subsection{Analisis Vector Autoregression Estimates}

Estimasi Vector Autoregression

0.154debagai berikut:

\begin{tabular}{|c|c|c|c|c|c|c|c|c|}
\hline \multirow{3}{*}{$\begin{array}{l}\text { DKURS does not Granger Cause } \\
\text { DPDB } \\
\text { DPDB does not Granger Cause } \\
\text { DKURS }\end{array}$} & \multirow{3}{*}{20} & \multirow{2}{*}{0.26173} & \multirow{2}{*}{0.6155} & & \multicolumn{4}{|c|}{ Estimasi VAR } \\
\hline & & & & & DPDB & DJUB & DINFLASI & DKURS \\
\hline & & 8.20788 & $0.010 \overline{\overline{7}}$ & \multirow{2}{*}{$\begin{array}{c} \\
\text { DPDB } \\
(-1)\end{array}$} & & & & \\
\hline $\begin{array}{l}\text { DINFLASI does not Granger Cause } \\
\text { DJUB } \\
\text { DJUB does not Granger Cause }\end{array}$ & \multirow[t]{2}{*}{20} & 0.00339 & 0.9543 & & $\begin{array}{r}-0.183384 \\
(0.25802) \\
{[-0.71074]}\end{array}$ & $\begin{array}{r}9.03 \mathrm{E}-05 \\
(0.00778) \\
{[0.01161]}\end{array}$ & $\begin{array}{r}1.12 \mathrm{E}-06 \\
(3.4 \mathrm{E}-06) \\
{[0.33355]}\end{array}$ & $\begin{array}{l}0.000185 \\
(0.00021) \\
{[0.86178]}\end{array}$ \\
\hline DINFLASI & & 2.84974 & 0.1096 & $\mathrm{JUUB}(-1)$ & 14.43018 & 1.106742 & $-1.41 \mathrm{E}-05$ & 0.000419 \\
\hline \multirow{2}{*}{$\begin{array}{l}\text { DKURS does not Granger Cause DJUB } \\
\text { DJUB does not Granger Cause } \\
\text { DKURS }\end{array}$} & \multirow[t]{2}{*}{20} & 0.00044 & 0.9835 & & $\begin{array}{r}(3.03034) \\
{[4.76189]}\end{array}$ & $\begin{array}{r}(0.09132) \\
{[12.1198]}\end{array}$ & $\begin{array}{r}(3.9 \mathrm{E}-05) \\
{[-0.35909]}\end{array}$ & $\begin{array}{r}(0.00252) \\
{[0.16627]}\end{array}$ \\
\hline & & 7.23323 & $0.0155_{\mathrm{Y}}$ & DINFLA & & & & \\
\hline $\begin{array}{l}\text { DKURS does not Granger Cause } \\
\text { DINFLASI } \\
\text { DINFLASI does not Granger Cause } \\
\text { DKURS }\end{array}$ & 20 & 5.34425 & 0.0336 & $\begin{array}{c}\text { SI } \\
(-1)\end{array}$ & $\begin{array}{r}3505.525 \\
(18463.8) \\
{[0.18986]}\end{array}$ & $\begin{array}{r}-32.90013 \\
(556.391) \\
{[-0.05913]}\end{array}$ & $\begin{array}{r}-0.132390 \\
(0.24005) \\
{[-0.55150]}\end{array}$ & $\begin{array}{r}-21.29626 \\
(15.3403 \\
{[-1.38825}\end{array}$ \\
\hline \multicolumn{3}{|c|}{ Sumber: Hasil Pengolahan Data, 2019} & & SURS(- & & & & \\
\hline $\begin{array}{l}\text { Berdasarkan tabel } 6 \\
\text { pendapatan nasianal }(\mathrm{PDB})\end{array}$ & $\begin{array}{l}\text { liatas, } \\
\text { ecara }\end{array}$ & $\begin{array}{l}\text { variabel } \\
\text { statistik }\end{array}$ & & 1) & $\begin{array}{r}-93.40166 \\
(163.786) \\
{[-0.57027]}\end{array}$ & $\begin{array}{r}0.147950 \\
(4.93554) \\
{[0.02998]}\end{array}$ & $\begin{array}{r}-0.002980 \\
(0.00213) \\
{[-1.39951]}\end{array}$ & $\begin{array}{l}0.471987 \\
(0.13608) \\
{[3.46849]}\end{array}$ \\
\hline $\begin{array}{l}\text { signifikan mempengaruhi nilai } \\
\text { beredar (JUB) dengan nilai prob }\end{array}$ & $\begin{array}{l}\text { jum } \\
\text { lebih }\end{array}$ & $\begin{array}{l}\text { lah uang } \\
\text { kecil dari }\end{array}$ & & $\mathrm{C}$ & $\begin{array}{l}-5632.735 \\
(1198147)\end{array}$ & $\begin{array}{r}11856.69 \\
(36105.1)\end{array}$ & $\begin{array}{l}41.20533 \\
(15.5774)\end{array}$ & $\begin{array}{l}4718.075 \\
(995.456)\end{array}$ \\
\hline 0,05 yaitu 0.0001 berarti tolak $h$ & potes & is nol dan & & & {$[-0.00470]$} & [ 0.32839] & [ 2.64520] & [ 4.73961] \\
\hline
\end{tabular}
variabel jumlah uang beredar (JUB) secara statistik tidak signifikan mempengaruhi variabel pendapatan nasional (PDB) yang dibuktikan dengan nilai prob masing-masing variabel lebih besar dari 0,05 yaitu 0,9883 sehingga dapat disimpulkan terjadi kausalitas satu arah antara kedua variabel PDB dan JUB. Kemudian yang kedua variabel pendapatan nasional (PDB) secara statistik tidak signifikan mempengaruhi variabel INFLASI dan begitu pula sebaliknya variabel INFLASI secara statistik tidak mempengaruhi variabel pendapatan nasional (PDB) yang dibuktikan nilai probabilitas masing-masing variabel lebih besar dari 0,05 yaitu0,8437 dan 0,1541 (hasil keduanya adalah terima hipotesis nol) sehingga disimpulkan tidak terjadi kaulitas apapun untuk kedua variabel PDB dan INFLASI. Selanjutnya yang ketiga, variabel pendapatan nasional (PDB) secara statistik signifikan

$(\mathrm{VAR})$

Sumber: Hasil Pengolahan Data, 2019

Berdasarkan tabel 7 di atas, dengan t-tabel 2,1009 maka variabel PDB berpengaruh negatif dan tidak signifikan terhadap dirinya sendiri hal ini dapat dilihat dengan nilai t hitung lebih kecil dari $t$ tabel yaitu sebesar $-0,71074<2,1009$. Varibel JUB berpengaruh positif dan signifikan terhadap pendapatan nasional hal ini dapat dilihat dengan nilai $\mathrm{t}$ hitung lebih besar dari t tabel yaitu sebesar $4,76189>2,1009$. Variabel inflasi berpengaruh positif dan tidak signifikan terhadap pendapatan nasional hal ini dapat dilihat dengan nilai t hitung lebih kecil dari $\mathrm{t}$ tabel yaitu sebesar 0,18986 $<2,1009$. Serta variabel kurs berpengaruh negatif dan tidak signifikan terhadap pendapatan nasional selama periode penelitian ini hal ini dapat dilihat dengan nilai t hitung lebih kecil dari t tabel yaitu sebesar $-0,57027<2,1009$. Ketentuan penggunaan 
t-hitung dibandingkan dengan t-tabel yaitu sesuai dengan penelitian yang oleh (Priyono \& Wirathi, 2016) dan (Aditya \& Sudirman, 2014).

\section{Analisis Impulse Response}

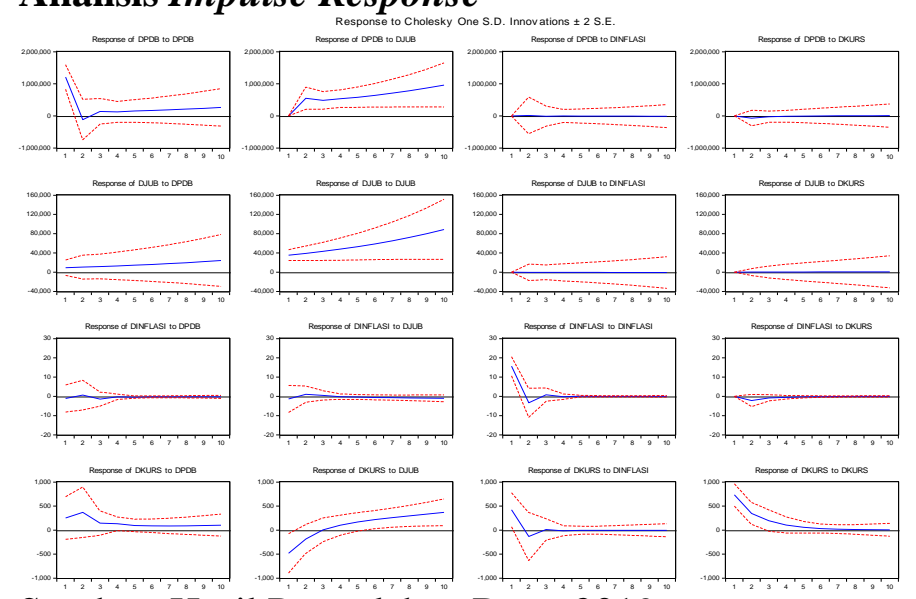

Sumber: Hasil Pengolahan Data, 2019

Gambar 6

Response Fungction

Pada Gambar 6 terlihat bahwa pada awal tahun pertama PDB mengalami peningkatan yang signifikan dn pada priode kedua terjadi guncangan terhadap variabel itu sendiri sehingga pendapatan nasional mengalami penurunan. Namun pada tahun ketiga kembali stabil sampai pada tahun kesepuluh. Artinya butuh waktu satu tahun untuk mencapai titik kesimbangan atau equilibriumnya setelah terjadinya shcok.

Sedangkan variabel jumlah uang beredar dari awal tahun sampai tahun kedua saat baik yaitu berada pada titik kesimbangan, dan pada tahun ketiga sampai kesepuluh terus mengalami peningkatan terhadap pendapatan nasional. Artinya butuh waktu satu tahun untuk variabel jumlah uang beredar kembali stabil. Respon variabel inflasi dari tahun pertama sampai tahun keempat menurun signifikan dan negatif serta tahun kelima mencapai titik kesimbangan atau equilibriumnya. Artinya butuh waktu empat tahun agar pendapatan nasional mengalami kestabilan setelah terjadi shock pada inflasi. Kemudian respon kurs mengalami fluktuasi dari tahun pertama mengalami peningkatan dan menurun pada tahun ketiga dan pada tahun keempat dan kelima inflasi turun dan naik. Sedangkan pada tahun kelima kurs kembali stabil atau mencapai titik keseimbangan setelah terjadinya shock. Artinya butuh waktu 3 tahun agar pendapatan nasional mengalami kestabilan setelah terjadi shock pada variabel kurs.

\section{Analisis Variance Decomposition}

Hasil analisis FEVD untuk variabel pendapatan nasional selama 22 tahun dapat dilihat pada Tabel 8.

\begin{tabular}{|c|c|c|c|c|c|}
\hline \multirow[b]{2}{*}{$\begin{array}{l}\text { Peri } \\
\text { od }\end{array}$} & \multicolumn{5}{|c|}{$\begin{array}{c}\text { Tabel } 4.8 \\
\text { Variance Decomposition }\end{array}$} \\
\hline & S.E. & DPDB & DJUB & $\begin{array}{l}\text { DINFLAS } \\
\text { I }\end{array}$ & DKURS \\
\hline 1 & & & & & \\
\hline 2 & 1338 & 82.8 & 16.90677 & 0.013081 & 645 \\
\hline 3 & 1430389. & 73.47276 & 26.25048 & 0.015047 & 0.261713 \\
\hline 4 & & 64.6 & 35. & 0.013336 & 35318 \\
\hline 5 & 1646576. & 56.87157 & 42.91102 & 0.012724 & 0.204683 \\
\hline 6 & 1775293. & 49.84599 & 49.96587 & 0.012067 & 0.176078 \\
\hline 7 & 1920951. & 43.56409 & 56.27370 & 0.011613 & 0.150595 \\
\hline 8 & 2085684. & 37.99622 & 61.86431 & 0.011235 & 0.128231 \\
\hline 9 & 2271639. & & 66.76538 & 0.010928 & 0.108775 \\
\hline 10 & 2481076 . & 28.88048 & 71.01687 & 0.010670 & 0.091985 \\
\hline
\end{tabular}

Sumber : Hasil Pengolahan Data, 2019

Berdasarkan tabel 8 pengujian variance decomposition yaitu pada periode pertama 100 persen variabilitas PDB dijelaskan oleh variabel itu sendiri, sementara dari JUB, INFLASI dan KURS adalah 0 persen. Begitu juga dengan variabel JUB,INFLASI dan KURS 100 persen dijelaskan oleh variabel itu sendiri, sementara dari PDB adalah 0 persen. Pada periode kedua, variabilitas PDB dijelaskan oleh rata-rata PDB itu sendiri sebesar 82.81 persen, sementara dari variabel JUB sebesar 16.90 persen, sementara dari variabel INFLASI sebesar 0.01 persen dan variabel KURS sebesar 0.26 persen. Pada periode ketiga variabilitas $\mathrm{PDB}$ dijelaskan oleh rata-rata variabel PDB itu sendiri sebesar 73.47 persen, sementara variabel JUB sebesar 26.25 persen. Sementara variabel INFLASI sebesar 0.01 dan variabel KURS sebesar 0.26 persen. Kemudian pada periode keempat variabilitas PDB dijelaskan oleh rata-rata PDB itu sendiri adalah sebesar 64.65 persen, sementara dijelaskan oleh variabel JUB sebesar 35.09189 persen, sementara variabel INFLASI sebesar 0.01 dan variabel KURS sebesar 0.23 persen. Kemudian pada periode kelima variabilitas PDB dijelaskan oleh rata-rata PDB itu sendiri adalah sebesar 56.87 persen, sementara dijelaskan oleh variabel JUB sebesar 42.91 persen, sementara variabel INFLASI sebesar 0.01 dan variabel KURS sebesar 0.20 persen. Lanjut pada periode keenam variabilitas PDB dijelaskan oleh rata-rata PDB itu sendiri adalah sebesar 49.84 persen, sementara dari variabel JUB sebesar 49.96 persen, sementara variabel INFLASI sebesar 0.01 dan variabel adalah sebesar 0.17 persen. Pada periode berikutnya sampai dengan periode 10 variabilitas PDB dijelaskan oleh rata-rata PDB itu sendiri semakin 
mengecil yaitu sebesar 28.88 persen. Sampai periode 10 PDB dijelaskan oleh variabel itu sendiri semakin mengecil, sementara dari variabel JUB, INFLASI dan KURS semakin meningkat. Dari penjelasan tersebut dapat disimpulkan bahwa jumlah uang beredar, inflasi dan nilai tukar rupiah memberikan kontribusi yang besar terhadap pendapatan nasional.

\section{Pembahasan}

\section{Hubungan Jumlah Uang Beredar Terhadap Pendapatan Nasional}

Berdasarkan hasil pengujian yang telah dilakukan dapat disimpulkan bahwa jumlah uang beredar memiliki hubungan positif dan singnifikan terhadap pendapatan nasional. Hasil penelitian ini sejalan dengan penelitian yang dilakukan oleh Tambunan \& Nory, (2015) dimana variabel jumlah uang beredar berpengaruh terhadap PDB di Indonesia, karena semakin bertambahnya jumlah uang beredar di masyarakat cenderung akan menambah konsumsi melalui belanja.

\section{Hubungan Inflasi Terhadap Pendapatan Nasional}

Berdasarkan hasil pengujian yang telah dilakukan dapat disimpulkan bahwa inflasi memiliki hubungan positif dan tidak signifikan terhadap pendapatan nasional. Penelitian ini didukung pula oleh penelitian yang dilakukan ogle Yudisthina \& Budhiasa, (2013), dengan judul pengaruh antara konsumsi, investasi, dan inflasi terhadap Produk Domestik Bruto (PDB) di Indonesia 2000-2012. Dimana varibel inflasi tidak pengaruh signifikan atau tidak memiliki pengaruh terhadap produk domestik bruto di Indonesia 2000-2012. Hal ini dikarnakan adanya inflasi berpengaruh tidak secara langsung.

Penelitian ini tidak sejalan dengan penelitian yang dilakukan oleh Larasati \& Sulastmiyati, (2018) dengan judul Pengaruh Inflasi, Ekspor, dan Tenaga kerja Terhadap Produk Domestik Bruto (PDB) di Indonesia. Dimana variabel inflasi memiliki pengaruh atau signifikan terhadap produk domestik bruto di indonesia.

\section{Hubungan Kurs Terhadap Pendapatan Nasional}

Berdasarkan hasil pengujian yang telah dilakukan dapat disimpulkan bahwa nulai tukar rupiah memiliki hubungan negatif dan tidak signifikan terhadap pendapatan nasional. penelitian yang dilakukan oleh Anggraini, (2017) dengan judul Analisis pengaruh kebijakan moneter terhadap produk domestik bruto di Indonesia. Dimana variabel kurs tidak pengaruh signifikan terhadap produk domestik bruto di indonesia. Hal ini dikarnakan adanya penyebab pertumbuhan produksi dalam negeri sebagai pendapatan domestik bagi negara mengalami penurunan karena sektor usaha tidak mampu membeli bahan pendukung produksi yang relatif tinggi.

\section{KESIMPULAN DAN SARAN Kesimpulan}

Berdasarkan hasil penelitian yang telah dilakukan maka dapat disimpulkan beberapa kesimpulan diantaranya adalah sebagai berikut:

1. Jumlah uang beredar berpengaruh poitif dan signifikan terhadap pendapatan nacional. Kemudian dengan análisis inpulse respon jumlah uang beredar membutuhkan waktu satu tahun untuk kembali stabil akibat guncangan yang disebabkan oleh variabel lain dalam penelitian.

2. Inflasi berpengaruh positif dan tidak signifikan terhadap pendapatan nasional selama periode penelitian. Kemudian berdasarkan análisis inpulse respon inflasi butuh waktu empat tahun untuk kembali stabil setelah terjadinya shcok.

3. Kurs berpengaruh negatif dan tidak signifikan terhadap pendapatan nasional. Kemudian berdasarkan análisis inpulse kurs butuh waktu tiga tahun untuk dapat kembali stabil setelah terjadinya shock.

\section{Saran}

Berdasarkan kkesimpulan yang telah dikemukakan di atas maka yang menjadi saran dalam penelitian ini adalah:

1. Pemerintah Indonesia diharapkan masyarakat untuk bijak dalam membelanjakan uangnya pada pos-pos produktif seperti investasi dan deposito, sehingga uang itu tidak beredarpada tempat yang konsunti.

2. Pemerintah Indonesia diharapkan dapat membuat kebijakan yang dapat menekan tingkat inflasi sehingga tidak sampai hiperinflasi melalui kebijakan fiscal dan kebijakan moneter.

3. Pemerintah Indonesia melalui berbagai kebijakannya hendaknya dapat menjaga kestabilan harga yang diproduksi serta berupaya selalu meningkatkan kualitas serta 
kuantitas agar dapat meningkatkan pendapatan nasional di Indonesia.

4. Untuk Peneliti yang melakukan penelitian sejenis, penulis menyarankan agar menambah variabel lain yang mempengaruhi pendapatan nasional dan menggunakan metode penelitian lain dalam menganalisis data.

\section{DAFTAR PUSTAKA}

Ervani, E. V. A. (2004). Analisis Faktor-Faktor yang Mempengaruhi Pertumbuhan Ekonomi Periode tahun 1980.1-2004.IV. 7(2), 17-18.

Boediono. (2008). Ekonomi Moneter.

Gujarati, D. N. (2006). Dasar-Dasar Ekonometrika. Edisi Ketiga. In Jakarta: Erlangga.

Gujarati, D. N., \& Porter, D. C. (2012). DasarDasar Ekonometrika. Edisi Lima. In Jakarta: Salemba Empat.

Mankiw, N. Gregory. (2006). Makro Ekonomi Edisi Keenam. Jakarta: Erlangga.

Natsir, M. (2014). Ekonomi Moneter dan Kebanksentralan. Jakarta: Mitra Wacana Media.

Nuri Angraini.2012. Analisis Pendapatan Nasional,Tingkat Suku Bunga SBi Dan Giro Wajib minimum Terhadap Jumlah Uang Beredar di Indonesia.

Todaro, Michael P dan Smith, Stephen 2003. Pembangunan Ekonomi di Dunia Ketiga. Jakarta: Erlangga.

Widarjono, A. (2007). Ekonometrika Teori dan Aplikasi untuk Ekonomi dan Bisnis, Edisi Kedua, Cetakan Kesatu, Penerbit Ekonisia Fakultas Ekonomi UII Yogyakarta.

Widarjano, A. (2013). Ekonometrika. Edisi Keempat. In Yogyakarta.

Yuliadi, Imamudin., (2008), Ekonomi Moneter, Cetakan I, PT. INDEKS, Jakarta.

Sukirno, Sadono, 2005. Mikro Ekonomi Teori Pengantar, Edisi Ketiga, Raja Grafindo Persada, Jakarta.
Sukirno, Sadono. (2010). Makroekonomi Teori Pengantar Edisi Ketiga. Jakarta: Rajawali Pers. 